\title{
A MAQUINARIA E O AUMENTO NA PRODUTIVIDADE PELO TRABALHO INTELECTUAL: OBSERVAÇÕES A PARTIR DE KARL MARX. ${ }^{1}$
}

\author{
Wanderson Pereira Araújo²
}

\begin{abstract}
Resumo
Este artigo analisa o trabalho intelectual na complexidade da atividade docente, inserido na formação profissional dos trabalhadores e na produção e aplicação da ciência e da tecnologia no campo da agricultura. Este estudo demonstra a relação do trabalho docente na reprodução ampliada do capital, que aparece ou que pode aparecer como expressão e condição geradora de valor, tendo como base observações de atividades docentes realizadas nos Institutos Federais (IFs). Nesse intento, utilizam-se algumas observações, a partir Karl Marx (em O Capital), em relação à teoria do valor, à categoria trabalho produtivo/improdutivo, bem como a outras, para compreender a dimensão dessa problemática na atualidade.
\end{abstract}

Palavras-chave: Produtividade; trabalho intelectual; Marx.

\begin{abstract}
This article analyzes the intellectual work in the complexity of the educational activity, inserted in the workers' professional formation and in the production and application of the science and of the technology in the field of the agriculture. This study demonstrates the relationship of the educational work in the enlarged reproduction of the capital, that appears or that can appear as expression and generating condition of value, tends as base observations of educational activities accomplished at the Federal (IFs) Institutes. In that project, some observations are used, to break Karl Marx (The Capital), in relation to the theory of the value, to the category work productive / unproductive, as well as the other ones, to understand the dimension of that problem at the present time.
\end{abstract}

Keywords: Productivity; intellectual work; Marx.

\footnotetext{
${ }^{1}$ DOI: https://doi.org/10.22409/tn.16i29.p4644

2 Doutorando em Educação pela FaE/UFMG; Professor do Ensino Básico, Técnico e Tecnológico da área de Fundamentos da Educação do Instituto Federal do Norte de Minas Gerais (IFNMG); membro do Grupo de Pesquisas e Estudos Marx, Trabalho e Educação (GEPMTE).

E-mail: wanderson_pa@yahoo.com.br
} 


\section{Introdução}

Nosso objetivo neste artigo é analisar o trabalho intelectual na complexidade da atividade docente no campo da ciência e da tecnologia aplicada à agricultura e às agroindústrias de alimentos. Analisamos a relação do trabalho intelectual com o processo de valorização, entendendo que a capacidade de trabalho do sujeito intelectual, em um processo contínuo de transformação das condições objetivas de trabalho, apresenta-se nas circunstâncias que aqui demonstramos como componente de um processo que produz e que transfere valor.

É à luz dessa questão que discutiremos a categoria trabalho produtivo em Marx, de maneira particular, com a nossa interpretação na fase contemporânea do capitalismo, sem anular de modo algum a perspectiva geral de Marx sobre a categoria trabalho produtivo.

Busca-se observar o trabalho docente em duas unidades dos Institutos Federais de Educação, Ciência e Tecnologia, nas áreas das agroindústrias de alimentos e da mecanização na agricultura ${ }^{2}$, tendo em vista a ontologia do ser social em Marx, essa problematização põe em pauta a discussão sobre o caráter produtivo da atividade docente, verificando-se em que medida essa atividade incorpora valor ou não.

Para analisar a problemática do trabalho intelectual do docente, tomamos como objeto de análise a categoria trabalho produtivo no sistema de produção capitalista. Essa categoria é um elemento histórico e preciso para se compreender o germe da reprodução ampliada do capital.

Desse modo, organizamos, a priori, o texto em quatro pontos de reflexões, a saber: o primeiro diz respeito ao caráter do valor em Marx, e busca-se compreender alguns elementos sobre a teoria do valor, tais como o trabalho que cria valor de uso, o trabalho concreto e o trabalho que gera valor, o trabalho abstrato, entendendo a subordinação do primeiro em relação ao último no modo

\footnotetext{
2 Trata-se de uma pesquisa de doutorado em andamento, desenvolvida no Programa de PósGraduação em Educação da UFMG. Apresentamos, neste artigo, alguns elementos dessa pesquisa como pontos preliminares para uma reflexão crítica.
} 
particular de produção capitalista, a partir da crítica ontológica que Marx desenvolve em contraposição à economia política clássica de Smith e de Ricardo.

No segundo ponto apresenta-se uma breve análise do trabalho produtivo e do trabalho improdutivo sob o capital; examina-se também a relação entre trabalho produtivo e trabalho intelectual, tendo-se em vista o conteúdo material da atividade.

O terceiro refere-se às observações realizadas por Marx dedicadas ao desenvolvimento da maquinaria, em O Capital, no livro I. Em Marx (2013), a máquina (mais precisamente como sistema automático) não é um meio de trabalho do trabalhador individual, nessa parte, atentamos para o fato identificado por Marx acerca da revolução do processo de produção tributário do desenvolvimento científico-tecnológico, que tem origem a partir da "invenção" humana.

Nas análises de Marx, a máquina é expressão do trabalho humano objetivado; já no modo de produção especificamente capitalista, a máquina e a aplicação técnica da ciência tornam-se um potencial para aumentar o capital, esse autor descreve com clareza que a maquinaria nas mãos do capital gera as condições que favorecem o capitalista a se apropriar do trabalho alheio.

Por fim, o quarto ponto remete a uma discussão sobre o trabalho intelectual e sobre o aumento na produtividade do trabalho no campo da agricultura e da agroindústria de alimentos, a partir dos elementos da observação empírica realizada em duas unidades do Instituto Federal de Educação, Ciência e Tecnologia, constata-se que as atividades docentes no campo que estão inseridas, ao mesmo tempo em que humanizam a natureza, pela sua atividade produtiva e criativa, também transferem valor a um produto lucrativo para o capital.

Do ponto de vista da exposição, considerando-se o caráter produtivo do trabalho docente, verifica-se que sua atividade propicia, em certa medida, a transformação do valor de uso em grandeza do valor, aqui, chegamos à conclusão de que esse tipo de trabalho se manifesta também como trabalho produtivo subordinado à relação entre o trabalho e o capital. 


\section{A questão do valor em Marx}

No primeiro capítulo sobre a mercadoria, em O Capital, livro I, Marx (2013) esclarece a natureza da riqueza capitalista. Estudar a mercadoria não foi uma escolha ao acaso feita por Marx. O que ele procurava era mostrar de onde provinha a produção da riqueza capitalista. $\mathrm{Na}$ sua expressão, é a "imensa acumulação de mercadorias" que configura a forma elementar dessa riqueza.

Por essa razão, ele começa a sua análise a partir da categoria mercadoria. Marx, em sua busca pela compreensão da essência da riqueza capitalista, explica: "Um valor de uso ou um bem só possui, portanto, valor, porque nele está corporificado, materializado, trabalho humano abstrato" (MARX, 2013, p. 60), a sua constatação é de que a mercadoria (forma especial do produto do trabalho) é consequência do dispêndio de força de trabalho.

Marx enfatiza em sua obra o caráter histórico de toda a realidade econômica, e descreve que o valor de uso é o princípio fundamental para a constituição da estrutura do ser social; isto é, o valor de uso que se encontra fora da esfera de investigação da Economia Política é o pressuposto e o fundamento da existência da vida social. Marx parte do princípio de que "qualquer que seja a forma social da riqueza, os valores de uso constituem sempre seu conteúdo, que permanece em primeiro lugar, indiferentemente a essa forma" (MARX, 2008, p. 52).

Nesse sentido, o autor ressalta que o valor de uso fora do modo de produção capitalista é produto do trabalho como resultado do trabalho em geral; ou seja, o valor de uso constitui o "conteúdo material da riqueza", qualquer que seja a formação social.

O valor de uso, ainda que seja objeto de necessidades sociais e que se articule com a sociedade, não expressa uma "relação de produção social", diz Marx. O valor de uso, na expressão de Marx, indiferente a qualquer formação social, não tem valor senão para 0 uso, e não adquire realidade senão no processo de consumo. Esclarece Marx (2008, p. 53): "Os valores de uso são, de modo imediato, meios de existência"; estes são produtos da vida social, originários da força vital gestada pelo homem, de trabalho objetivado. Assim 
representa a materialização da natureza pelo trabalho humano. Esta mediação universal do homem com a natureza representa a determinação ontológica fundamental da humanidade ${ }^{3}$. No entanto, na forma capitalista de produção, essa atividade produtiva é subsumida ao trabalho abstrato e está sujeita, por exemplo, às mediações "propriedade privada", "intercâmbio" e "divisão do trabalho", que se interpõem entre o homem e sua atividade (MÉSZÁROS, 2006).

O valor de uso, quando é "determinando de forma econômica", torna-se diretamente base material de que se manifesta uma relação denominada de valor de troca. Para Marx, o valor de troca aparece "como uma relação quantitativa na qual os valores de uso são permutáveis" (MARX, 2008, p. 54).

Pergunta-se Marx: o que ocorrerá com o trabalho complexo que se eleva acima do nível médio como trabalho de maior intensidade e de peso específico superior? A lei que regula a redução do trabalho é valor de troca (um dia de trabalho complexo equivale a três dias de trabalho simples). Para Marx, está claro que essa redução tem lugar:

[...] pois, enquanto é valor de troca, o produto do trabalho mais complexo é, em proporção determinada, o equivalente do produto do trabalho médio simples; forma, portanto, equação com um quantum determinado desse trabalho simples (MARX, 2008, p. 5657).

Marx esclarece que o trabalho complexo é trabalho simples composto, ou seja, o trabalho complexo é trabalho simples de potência mais elevada.

Da análise do valor a partir de Marx, concluímos de forma breve que o valor de uso, substância indiferente à relação econômica formal, no capitalismo, se distingue. $O$ fator determinante do valor é a quantidade do trabalho necessário para a produção de uma mercadoria, daí o trabalho se manifesta em valor de troca. Segundo Marx:

O tempo de trabalho do indivíduo é, desse modo, em realidade, o tempo de trabalho que a sociedade deve gastar para produzir um valor de uso determinado, isto é, para satisfazer uma necessidade determinada (MARX, 2008, p. 58).

\footnotetext{
${ }^{3}$ Ver mais a respeito da teoria da alienação em Marx em: MÉZSÁROS, I. A teoria da alienação em Marx. São Paulo: Boitempo, 2006 (capítulo 2).
} 
Em outras palavras, o valor de troca é uma determinação histórica, enquanto o valor de uso, independentemente de sua forma histórica, é, de modo imediato, meio de existência, como já evidenciamos; isto é, o dispêndio da força de trabalho humana é a substância social que faz o valor de uso manifestar valores. Segundo Marx (2013, p. 58), em O Capital: "Os valores de uso constituem o conteúdo material da riqueza, qualquer que seja a forma social dela". O exame que Marx faz sobre o valor de uso independe do modo de produção capitalista e se refere à manifestação ou ao resultado do trabalho em geral, o trabalho na sua condição eterna da existência humana. $O$ valor de uso, na forma capitalista de produção, forma histórica, é portador material do valor de troca (Idem).

Para Marx, o trabalho, em uma forma determinada da organização social do trabalho, numa forma de produção historicamente determinada, assume uma qualidade social nova: é trabalho abstrato ${ }^{4}$. Afirma Marx:

Ao desvanecer o caráter útil dos produtos do trabalho, também desaparece o caráter útil dos trabalhos neles corporificados; desvanecem-se, portanto, as diferentes formas de trabalho concreto, elas não mais se distinguem umas das outras, mas reduzem-se, todas, a uma única espécie de trabalho, o trabalho humano abstrato (MARX, 2013, p. 60).

Os produtos dos trabalhos no modo de produção capitalista representam a massa do dispêndio da força de trabalho humano, sem consideração pela forma como foi despendida; representam apenas a força de trabalho gasta em sua produção, trabalho humano armazenado. Assim, "como configuração dessa substância social que lhe é comum, são valores, valores-mercadorias" (Idem).

\footnotetext{
${ }^{4}$ De acordo com Teixeira (1995, p. 71): "Mas o que se deve entender por trabalho abstrato? A resposta de imediato é a seguinte: por trabalho abstrato deve se entender uma forma histórica de igualação ou socialização dos diversos trabalhos privados, que se realizam independentemente uns dos outros. Na forma social capitalista, porque os homens se defrontam como produtores privados de mercadorias, seus produtos só podem participar do sistema de realização das necessidades sociais mediante a troca. Ao trocarem seus produtos uns pelos outros os produtos estão, na verdade, igualando entre si seus diferentes trabalhos, embora disso não tenham consciência. 'ao equipararem seus produtos de diferentes espécies na troca, como valores' esclarece Marx, 'equiparam seus diferentes trabalhos como trabalho humano. Não o sabem, mas o fazem' (O Capital, Liv. I, Vol. p. 72)”.
} 
Em outras palavras, Marx explica que um valor de uso ou bem só passa a possuir valor porque nele está corporificado, materializado, o "trabalho humano abstrato"; portanto, a substância constituidora do valor só pode ser o trabalho. Mais adiante Marx abrevia: "O que determina a grandeza do valor, portanto, é a quantidade de trabalho socialmente necessário ou o tempo de trabalho socialmente necessário para produção de um valor de uso" (Ibidem, p. 61).

É importante salientar que, na mercadoria, encontramos simultaneamente trabalho concreto e trabalho abstrato. Não se trata de dois tipos de trabalho, "trata-se de apreciação do mesmo trabalho sob ângulos diferentes: do ângulo do valor de uso, trabalho concreto; do ângulo do valor de troca, trabalho abstrato" (NETTO; BRAZ, 2012, p. 118).

Fica esclarecido que, no modo de produção capitalista, o produto do trabalho representa um determinado volume de trabalho materializado; portanto, a substância do trabalho, ou seja, a atividade produtora ou o trabalho humano abstrato constitui a forma e o conteúdo do valor. A título de exemplo, tem-se hoje o trabalho intelectual envolvido na produção de técnicas e de metodologias (por exemplo, o método in vitro) que modificam as culturas de células e tecidos, utilizando-se da tecnologia do Ácido Desoxirribonucleico (DNA) recombinante para a produção e para a reprodução de plantas de milho e outras (por exemplo: o milho $\left.B t^{5}\right)$. Tal realidade representa um exemplo claro da questão do trabalho que produz a substância dos valores a partir da natureza.

Esse trabalho se constitui trabalho concreto, como fonte de riqueza material; em suma, é uma atividade produtora de valores de uso. Mas aqui reside uma questão importante do ponto de vista do capital. Os organismos geneticamente modificados (plantas, animais, microrganismos) por meio de técnicas criadas pela engenharia genética e pela biotecnologia têm sido considerados pelos grandes empreendedores do mercado como "alternativa fundamental" (LONDRES, s/d) para o aumento da produtividade, para a redução

\footnotetext{
${ }^{5}$ Segundo a definição da Embrapa (2011), o milho Bt é o milho geneticamente modificado no qual foram introduzidos genes específicos da bactéria de solo, Bacillus thuringiensis (Bt), que promove na planta a produção de uma proteína tóxica específica para determinados grupos de insetos.
} 
de custos de produção e para a maior extração de lucro; com isso, mantida a relação com o mercado internacional.

$\mathrm{Na}$ forma capitalista de produção, o trabalho concreto ${ }^{6}$ é subordinado ao trabalho abstrato ${ }^{7}$. O produto do trabalho intelectual docente assume um caráter determinado, uma nova forma social: a de mercadoria. No exemplo, o trabalho intelectual docente está incorporado no objeto do seu trabalho, materializa uma qualidade útil sobre a natureza. Determinada qualidade é a expressão do valor, ou seja, a atividade intelectual agrega valor a um produto que, sob o domínio do capital, se torna propriedade privada e não atende às necessidades imediatas da humanidade; meio de apropriar-se de mais capital, portanto, significa trabalho que valoriza o capital, "trabalho humano abstrato".

O trabalho docente observado nos Institutos Federais (IFs) na formação dos trabalhadores direcionados à agricultura apresenta características importantes do ponto de vista da reprodução social, tanto do indivíduo quanto da sociedade. Além do envolvimento na formação da pretensa força de trabalho qualificada, está envolvido (o trabalho docente) na mediação e na transformação dos elementos naturais em meios de produção, tais como a utilização e o incremento da tecnologia de alimentos (professor da área de Processamento de Alimentos) e da tecnologia associada à agricultura mecanizada (professor da área de Mecanização e Automação). O trabalho docente desenvolve atividades constitutivas de uma dimensão ontológica que envolve a relação entre os indivíduos e a produção científica, por exemplo, formação de personalidades mais qualificadas, bem como a implementação e a criação de inovações tecnológicas, um dos elementos componentes da sua atividade, e liga-se substantivamente às forças produtivas do trabalho.

\section{A categoria trabalho produtivo/improdutivo em Marx}

\footnotetext{
${ }^{6} \mathrm{~A}$ categoria trabalho concreto é compreendida por Marx como a eterna necessidade natural de mediação do intercâmbio entre o homem e a natureza. Diz ele: "Como criador de valores de uso, como trabalho útil, é o trabalho, por isso, uma existência do homem, independente de toda forma de sociedade, eterna necessidade natural de mediação do metabolismo entre homem e natureza e, portanto, da vida humana" (O Capital, MARX, 2013, p. 120).
}

${ }^{7}$ Aquele que gera o valor da mercadoria (O Capital, MARX, 2013). 
Marx, no capítulo VI, inédito, de O Capital, em contraposição à economia política clássica de A. Smith, diz:

Só a tacanhez mental da burguesia, que tem por absoluta a forma capitalista de produção, e que, consequentemente, a considera forma natural da produção, pode confundir a questão do trabalho produtivo, e do trabalho produtivo do ponto de vista do capital, com a questão do trabalho produtivo em geral, contentando-se assim com a resposta tautológica de que é produtivo todo o trabalho que produz, em geral, ou que desemboca num produto, ou num valor de uso, em resumo: num resultado. (MARX, 2014, p. 109).

Marx chama a atenção para o fato de que o trabalho produtivo, na perspectiva do capital, é determinante, sendo que o produto por excelência da produção capitalista é a mais-valia; portanto, o elemento fundamental para tal efetivação é a capacidade de trabalho. Segundo Marx, do ponto de vista do processo capitalista de produção:

[...] é produtivo aquele trabalho que valoriza diretamente o capital, o que produz mais-valia, ou seja, que se realiza - sem equivalente para o operário, para o executante - numa mais-valia representada por um subproduto (MARX, 2004, p. 109).

Isto é, trabalho que se realiza num incremento excedente de mercadoria para o capitalista. Em síntese: trabalho produtivo é aquele que serve ao capital como meio da sua autovalorização, como meio para a produção de mais-valia.

A compreensão de Marx sobre o caráter histórico e prático da natureza humana, que se constitui por meio das relações sociais, é puramente materialista. $\mathrm{Na}$ concepção de Marx, o trabalho como categoria fundante da sociabilidade, antes de qualquer coisa, deve ser compreendido como condição universal da existência humana; revela-se como "um processo de que participam o homem e a natureza, processo em que o ser humano, com sua própria ação, impulsiona, regula e controla seu intercâmbio material com a natureza" (MARX, 2013, p. 211). Portanto, o trabalho aparece como atividade criadora e reprodutora da vida, independente da formação social. 
No processo de trabalho, a atividade do homem transforma a natureza, "subordinada a um determinado fim", no objeto. Daí o produto da sua atividade é um valor de uso, "um material da natureza adaptado às necessidades humanas através da mudança de forma" (Idem). O que se manifestava em ser inerte revelase, depois da ação humana intencionada, em qualidade fixa, na forma de ser social. Nesse sentido, Marx abrevia que é diretamente trabalho produtivo aquele que produz valor de uso, mas deixa claro que caracterizá-lo de tal modo no capitalismo não é suficiente. Acrescenta:

No capítulo $\mathrm{V}$, estudamos o processo de trabalho em abstrato, independentemente de suas formas históricas, como um processo entre o homem e a natureza. Dizemos: 'observando-se todo o processo do ponto de vista do resultado, do produto, evidencia-se que meio e objeto de trabalho são meios de produção, e o trabalho é trabalho produtivo'. Na nota 7, acrescentamos: 'Essa conceituação de trabalho produtivo, derivada apenas do processo de trabalho, não é de modo nenhum adequada ao processo de produção capitalista' (MARX, 2014, p. 585).

Marx, ao longo de sua obra, vai explicitar essa questão, de modo que fica claro o seu sentido. Esclarece, por exemplo, que, no modo de produção capitalista, não basta produzir valor de uso. Para ser produtivo no processo de produção capitalista, o trabalho deve ser assalariado, e não só isso: o trabalho produtivo precisa também produzir valor de uso que seja veículo de troca. $\mathrm{O}$ trabalho produtivo, na acepção de Marx, corresponde a dois polos constituintes: efetiva uma riqueza material, é uma atividade produtiva para suprir a necessidade humana; por outro lado, toma forma social determinada historicamente, e se compreende pelo dispêndio de força de trabalho humano que valoriza o capital. Daí a crítica à "tacanhez mental da burguesia", que não compreende a forma e o conteúdo da riqueza material, abstraída da forma capitalista.

Em Teorias da mais-valia, Marx esclarece que tanto os trabalhadores manuais quanto os trabalhadores intelectuais são produtivos para o capital:

Nessa categoria de trabalhadores produtivos figuram naturalmente os que, seja como for, contribuem para produzir a mercadoria, desde 0 verdadeiro trabalhador manual até o gerente, o engenheiro (distintos do capitalista). (MARX, 1987, p. 136). 
A respeito da questão referente ao ato de "produzir mercadoria", apresentamos alguns esclarecimentos, considerando a determinação do valor pelo dispêndio da força de trabalho a partir de Marx, que percebeu a confusão e a contradição de Smith, ao tratar o trabalho produtivo como "aquele que produz 'mercadoria', e o improdutivo sendo aquele que não produz mercadoria alguma". Diferente de Smith, Marx considera a força de trabalho como uma forma de mercadoria, aquela cuja exteriorização é o próprio trabalho.

Ele chama a atenção para o fato de que a mercadoria é substância "dotada de existência diferente do próprio trabalho", e diz: é "certo que, a mercadoria se patenteia trabalho pretérito, objetivado e que, por isso, se não aparece na forma de uma coisa, só pode aparecer na forma da própria força de trabalho" (Idem). Isto é, a mercadoria aparece em duas categorias: força de trabalho e as próprias mercadorias. Marx vê a mercadoria como determinada quantidade de trabalho social, e continua: "É possível que o trabalho concreto de que resulta, nela não deixe vestígio" (MARX, 1987, p. 151).

Em termos gerais, Marx toma como ponto de partida a forma social ou capitalista de organização do trabalho para definir ou qualificar o trabalho produtivo. Segundo Rubin (1987, p. 287): "A participação do trabalho na produção de bens de consumo (não necessariamente bens materiais) representa, para Marx, uma propriedade adicional do caráter produtivo do trabalho, mas não seu critério".

O critério, para Marx, é exatamente a forma capitalista de organização do trabalho, "à sua concepção de que na sociedade capitalista a força motriz do desenvolvimento é o capital" (Idem). Em síntese, para Marx, trabalho produtivo é somente aquele que produz mais-valia, ou seja, trabalho produtivo é todo aquele que é empregado pelo capital e consumido no "processo de produção", com vista à valorização do capital (MARX, 2014, p. 108).

$\mathrm{Na}$ concepção de Marx, há trabalhos que não são improdutivos para o capital. Segundo Marx: "A diferença entre o trabalho produtivo e o improdutivo consiste tão somente no fato de o trabalho trocar-se por dinheiro como dinheiro ou por dinheiro como capital" (MARX, 2004, p. 119). Marx chega à constatação de 
que, no caso dos serviços, compra-se trabalho, mas se compra por seu valor de uso particular; trata-se de uma troca por dinheiro como dinheiro, ou seja, "na compra de serviços não está de maneira nenhuma contida a relação entre o trabalho e o capital" (Idem).

A partir de tal compreensão, chegamos à constatação de que a atividade científica do trabalho intelectual produz uma mercadoria que custa determinada quantidade de trabalho. Por exemplo, na agricultura, a forma adquirida da técnica mecanizada de produção de milho, trigo, arroz etc., por certo, é fruto de trabalho transmitido através de gerações e, em determinadas circunstâncias, o produto desse trabalho concreto e atual entra numa relação social de produção capitalista, como novos meios de produzir mais-valia.

\section{O aumento na produtividade do trabalho, o trabalho docente e a inovação tecnológica.}

Marx, ao explicar sobre o desenvolvimento da maquinaria, explicita o caráter ontológico de um estágio da produção e identifica a invenção científica como um elemento histórico-social originário da mediação do homem e da natureza. Noutras palavras, Marx vê como elemento do processo de trabalho a invenção científica como fator de contradição ${ }^{8}$ e de modificação do processo de produção.

Marx começa o capítulo XIII, intitulado "A maquinaria e a indústria moderna", em O Capital, afirmando qual é o objetivo da maquinaria, sob o domínio do capital, ao fazer uma correção em um trecho da obra de John Stuart Mill, em que ele se referia ao fato de ser "duvidoso que as invenções mecânicas feitas até agora tenham aliviado a labuta diária de algum ser humano" (MILL, apud MARX, 2013, p. 427).

Segundo Marx (2013), não é esse o objetivo do capital, quando emprega a maquinaria. O desenvolvimento da maquinaria como força produtiva do trabalho, produto do trabalho humano, sob o domínio do capital, tem como finalidade

\footnotetext{
${ }^{8}$ Segundo Marx (2013, p. 465): "Há, portanto, uma contradição imanente na aplicação da maquinaria para produzir mais-valia, pois, dos dois fatores da mais-valia obtida com um capital de magnitude dada, um fator, a taxa da mais-valia, só pode ser aumentado por essa aplicação se ela diminuir o outro fator, o número de trabalhadores".
} 
"baratear as mercadorias, encurtar a parte do dia de trabalho da qual precisa o trabalhador para si mesmo, para ampliar a outra parte que ele dá gratuitamente ao capitalista" (Ibidem, p. 427). Ou seja, a maquinaria no sistema capitalista é meio para produzir mais-valia. Depois dessa consideração, Marx, em nota de rodapé, faz uma correção na citação de Mill e escreve: "Mill deveria ter dito: De algum ser humano que não viva do trabalho alheio. As máquinas aumentam, certamente, o número dos abastados ociosos" (MARX, 2013, p. 427, nota 86).

A relação do homem com a natureza, em que as forças da natureza (vento, água, vapor etc.) são colocadas e controladas pelo homem a favor dos fins determinados pelo próprio homem, possibilitou a transformação de ferramentas manuais em máquinas. Assim, a força motriz exercida pelo homem é substituída por forças naturais. Todo esse desenvolvimento científico e técnico, ou seja, a aplicação da ciência como elemento da produção mecanizada, correspondia, para Marx, à revolução industrial.

Produzir tecnologia significa, na lei do mercado, diminuir os custos e aumentar a produtividade. Nesse sentido, Marx é atual, ao verificar que a dinâmica científica e tecnológica se tornava meio de expansão do capital. No campo da ciência natural, de modo particular, testemunhamos como se move o desenvolvimento científico sob o comando do capital. As observações acima nos permitem compreender a realidade atual como desdobramento da forma de produção social do homem, ou seja, como consequência do desenvolvimento histórico. Os pressupostos apresentados por Marx para a compreensão da realidade são fundamentais para a apreensão da dinâmica de acumulação de capital no estágio atual da sociedade capitalista.

Toda mudança de produção e de forma de apropriação de mais-trabalho é resultado das contradições entre forças produtivas e relações sociais de produção, com várias implicações e consequências. Tomamos como exemplo a aplicação da ciência e da tecnologia na agricultura e na agroindústria de processamento de alimentos, para demonstrar a continuidade do desenvolvimento do indivíduo social em determinadas atividades especializadas em que, ao se apropriar do conhecimento acumulado pelo gênero humano, cria, e não apenas reproduz novos métodos de produção. 
Sem dúvida, são atividades que se efetivam a partir do intercâmbio do homem com a natureza, novas formas de ser. $O$ homem regula e põe em movimento a natureza sob o seu domínio de forma cada vez mais complexa, desde o adestramento do animal até as mais sofisticadas máquinas (uso da energia, água, ar, processos químicos, minério etc.) e a automação.

O processo de produção de base técnica impulsiona uma contínua transformação do trabalho, modificando "[...] as funções dos trabalhadores e as combinações sociais do processo de trabalho" (MARX, 2013, p. 551). Marx destaca essa tendência mostrando que os processos de produção de base técnica, por sua natureza, exigem a variação do trabalho, isto é, novas funções vão surgindo com o desenvolvimento e com o aumento das forças produtivas, aperfeiçoando as formas de trabalho excedente. É uma contradição, pois esse processo, sob o domínio do capital, coloca em ameaça as condições de vida do trabalhador.

A produção de base técnica faz surgir formas diferentes e sucessivas de atividades $^{9}$, e isto é um fator importante que levou à necessidade de especialização e de qualificação de trabalhadores para o aperfeiçoamento e para o desenvolvimento da produção moderna. Nesse sentido, as escolas profissionais e tecnológicas aparecem como fatores desse processo de transformação no curso da contradição posta pelo capital: quanto mais se aumenta a força da aplicação da ciência, a força produtiva das máquinas, "tanto maior o serviço gratuito que prestam" ao capital. Ao mesmo tempo, com os pressupostos da indústria moderna, "aprende o homem a fazer o produto de seu trabalho passado, o trabalho já materializado, [...]" (MARX, 2013, p. 444).

\footnotetext{
${ }^{9} \mathrm{Na}$ agricultura, por exemplo, na produção mecanizada, não se utiliza mais a figura do tratorista, e sim a do operador de máquinas [nota de observação no campo de trabalho docente em mecanização]. Conforme Molin, Amaral e Colaço (2015, p. 214): "A cana-de açúcar tem os sistemas de direção automática como potenciais aliados, por se tratar de uma cultura semiperene. O seu sistema de produção consiste em diversas operações mecanizadas, empregadas desde a sua implantação, com o preparo do solo e plantio, passando pelos tratos culturais durante o seu desenvolvimento até chegar à colheita durante o estádio de maturação". Entretanto, o que os autores nos mostram é que o sistema operacional automático desenvolve na lavoura uma ação potencialmente produtiva, e que tal operação mecanizada depende de um operador de novo tipo. Nesse sentido, o cultivo e a colheita da cana-de-açúcar podem ilustrar a (re)produção e a aplicação do princípio automático.
} 
O caráter revolucionário da indústria moderna modificou profundamente diversos setores de produção. Por ora, aqui, evidenciaremos alguns elementos da relação social de produção na agricultura, mais detidamente a relação dos professores inseridos na formação profissional e tecnológica dos trabalhadores ligados diretamente à aplicação da tecnologia e da ciência na agricultura.

Segundo Marx (2013, p. 570), o modo de produção capitalista "[...] cria as condições materiais para uma síntese nova, superior, para a união da agricultura e da indústria". Na agricultura moderna, assim como na indústria, "o aumento da força produtiva e a maior mobilização do trabalho" se dão no progresso do despojamento do trabalhador, e esse é o progresso da agricultura capitalista.

$\mathrm{Na}$ atualidade, a dinâmica de exploração do trabalho tem se aprofundado com o desenvolvimento das forças produtivas do trabalho; um exemplo acentuado no campo da agricultura é, a expansão da forma de se produzir alimentos, que inclui a evolução da ciência, mecanismos de aplicação nas formas de processamento, bem como a industrialização de alimentos, o papel das agroindústrias de alimentos tem ampliado as formas de apropriação do lucro. A educação dos trabalhadores tem servido ao sistema capitalista como mediação social do desenvolvimento de habilidades e de ampliação dos meios de produção eficazes a novas formas de produção de natureza científica; nesse sentido, o trabalho docente aparece com a função social também de transferir ou de produzir valor de uso social. Podemos sinalizar como exemplo a atividade docente de um professor na área de Processamento de Alimentos, que envolve o ensino e a forma aplicada de como

\begin{abstract}
Aumentar o período durante 0 qual o alimento permanece adequado para o consumo (vida de prateleira) por meio de técnicas de preservação que inibam mudanças microbiológicas e bioquímicas, permitindo o tempo necessário para distribuição, vendas e armazenagem caseira (FELLOWS, 2006).
\end{abstract}

Envolve também a manipulação, o controle, a regulação e as descobertas das formas de reprodução biológica do ser vivo fora dos seus padrões naturais (por exemplo: a biotecnologia na produção alimentícia); trata-se, nessa particularidade, de uma objetivação que envolve mãos e cérebro. Em outras 
palavras, trata-se de uma atividade que transfere ao objeto uma sustância social, ou seja, dá origem a um 'valor de uso social' a partir do domínio das forças da natureza (Nota de observação n. 2; 2017).

Desse modo, verifica-se que a produção do trabalho docente não se restringe ou se limita, em dadas circunstâncias, à função de transmissão de conhecimentos científicos. Envolve também as modificações e a produção de instrumentos de trabalho em forma social, ou seja, em produtos inovadores que respondem satisfatoriamente às necessidades geradas no sistema produtivo. $O$ conteúdo do trabalho docente, em determinada proporção, contribui para o desenvolvimento das forças produtivas e, consequentemente, amplia a produtividade do trabalho.

A produção na agricultura e sua inter-relação com a indústria é um dos ramos mais lucrativos para o capitalismo na atualidade. Isso incide sobre a dinâmica de trabalho do professor quanto à formação dos trabalhadores para esse e para outros ramos da estrutura produtiva e quanto mais se desenvolve, no sentido de se reproduzir o capital, mais se aumenta a necessidade de transformação da base técnica de produção.

Nesse sentido, as escolas preparatórias de trabalhadores para o mercado aparecem como grandes oficinas de criação de invenções científicas ou de produções de tecnologias, para atender aos interesses demandados pelo grande mercado. No campo da agricultura, as ciências e as tecnologias aplicadas ganham proeminência no processo social de produção, propiciando, em alguma medida, a evolução das forças produtivas.

Mostramos aqui, a partir de algumas observações de Marx, que as tendências cristalizadas pelo avanço das ciências aplicadas ao modo de produção têm favorecido o incremento do capital; de forma mais aperfeiçoada, as relações de produção existentes até então contam com a atividade intelectual no campo da agricultura não mais somente na ampliação da maquinaria, mas também de atividades voltadas para a aplicação de tecnologias da informação associadas à máquina.

As estratégias da tecnologia da informação e de automação visam propiciar o aumento da produtividade com o mínimo de custo e de mão de obra. Tais 
estratégias respondem ao que os especialistas da área denominam de "potencial de resposta", ou seja, para maior lucratividade e menos custos, para alcançar maior exatidão econômica, os indivíduos criam as condições concretas para tal.

Essa observação pode ilustrar o trabalho docente no campo da mecanização agrícola, que envolve, além do ensino da ciência da mecânica, além da formação do operador de máquinas, simultaneamente, o incremento da inovação tecnológica aplicada à agricultura - o desenvolvimento de meios ou de ferramentas de trabalho dessa natureza é objeto da atividade docente tanto em universidades quanto nos Institutos Federais de Educação, Ciência e Tecnologia, onde as atividades de ensino e de pesquisa aplicada estão interligadas. $O$ trabalho docente observado no ramo da mecanização agrícola no IF, mais detidamente no Norte de Minas Gerais, incorpora aos mecanismos de produção agrícola inovações associadas à ferramenta denominada de Agricultura de Precisão (AP), compreendida como um conjunto de tecnologias que promovem melhorias no sistema de produção, com o auxílio de mecanização e de automação.

As técnicas desenvolvidas pelo trabalho intelectual docente criam estratégias que envolvem novas dimensões e o desenvolvimento da mecanização no cultivo do solo e das culturas; ou seja, o esforço da atividade intelectual viabiliza novas operações mecanizadas, associadas com outras habilidades de caráter tecnológico, levando em conta as diferenças das áreas produtivas.

Nesse sentido, pergunta-se: quais as consequências dessa atividade para a sociedade? Tal atividade, por um lado, amplia o potencial das forças produtivas, no sentido de garantir maior produtividade no campo da agricultura; a aplicação dessa ferramenta parametriza o uso e a quantidade adequada de insumos, bem como a utilização de energia, sementes e água.

Por outro lado, isso, nas mãos dos capitalistas, representa um meio de absorver mais-valor, isto é, propicia a maximização do lucro e a redução dos custos de produção. A natureza dessa atividade aparece como conteúdo que configura ou que transfere valor a um dado importante na valorização do capital.

Compreende-se que, para a reprodução do capital, é necessária a constante reprodução da classe trabalhadora. Após o advento da indústria 
moderna, o que importa aos capitalistas é uma classe trabalhadora, inclusive uma massa de trabalhadores qualificados, que, junto a uma massa de trabalhadores existentes ou desqualificados, impulsiona os processos de produção. Marx, em $O$ Capital, na parte sétima, sobre a Acumulação de capital, diz:

O capitalista considera a existência de uma classe trabalhadora dotada de habilidade entre as condições de produção que the pertencem; vê nela a existência real de seu capital variável (MARX, 2013, p. 677).

A fim de assegurar a reprodução ampliada e constante do capital, o Estado e as empresas capitalistas viabilizam as condições propícias para tal comandando o processo de formação dos trabalhadores, ou seja, utilizam-se dos mecanismos sociais para reforçar a exploração do trabalho, seja ele de caráter qualificado ou não. De forma mediata, contribui para a produção da força de trabalho que cria a riqueza alheia - estamos falando da formação adequada dos trabalhadores para a atual demanda do mercado, em que o contínuo "progresso tecnológico" na produção requer sempre novas invenções.

A função social do trabalho docente em tela está inserida na estrutura produtiva; não só atende à necessidade de autorreprodução do indivíduo, mas também se manifesta e favorece as condições concretas dos elementos formadores da possibilidade de levar a cabo a luta pela emancipação humana. Tal pressuposto faz do proletário docente um trabalhador produtivo.

Não se trata apenas de um trabalho qualificado que, a propósito, é considerado superior ou complexo em relação ao trabalho social médio, por razão da força de trabalho constituir-se a partir de um custo de aprendizagem maior ou superior; essa é uma lógica de mensuração efetivada pelo mercado. Marx, nesse sentido, observou que o valor dessa força é maior; consequentemente, manifesta um trabalho superior e se materializa em valores proporcionalmente maiores ${ }^{10}$.

Verificamos que o trabalho docente, em determinadas circunstâncias, manifesta-se como trabalho que incorpora valor, na medida em que produz uma objetivação capaz de multiplicar o valor que possui. Um mecanismo ou uma

10 O problema do trabalho qualificado pode ser conferido em Rosdolsky (2001, p. 432), a partir de O Capital, de Karl Marx. 
ferramenta de trabalho incrementada pela atividade docente, que assegura economia de tempo e de insumos, supõe, para o capital, mais-valia.

Na visão de Carcanholo (2008), os trabalhos dos professores, quaisquer que sejam, desempenham apenas um papel: transformar força de trabalho simples em força de trabalho potenciada ou complexa.

$\mathrm{O}$ autor percebe um lado do trabalho dos professores de modo geral, segundo esse autor, todo o trabalho que produz uma força de trabalho mais qualificada, ou mesmo aquele que simplesmente produz a sua manutenção, seja ele do setor privado ou do público, deve ser qualificado de produtivo no nível de abstração mais concreto (CARCANHOLO, 2008, p. 14).

$\mathrm{Na}$ análise que fazemos, destacamos um duplo caráter do trabalho docente: a transmissão de um conjunto de determinados saberes e o incremento de novos meios de produção, por meio da aplicação da ciência e de tecnologias; além de propiciar a formação qualificada, o docente, em determinadas circunstâncias, aparece como indivíduo produtor de inovações tecnológicas e de condições objetivas de produção.

Nesse sentido, o trabalho docente manifesta-se em mais-trabalho, pois, em certa medida, ele extrapola o trabalho necessário e cria os meios pelos quais o capital se valoriza e se reproduz. Essa afirmação é possível em decorrência de uma apreensão marxiana:

A produtividade do trabalho é determinada pelas mais diversas circunstâncias, dentre elas a destreza média dos trabalhadores, o grau de desenvolvimento da ciência e sua aplicação tecnológica, a organização social do processo de produção, o volume e a eficácia dos meios de produção e as condições naturais. (MARX, 2013, p. 62).

A produtividade do trabalho humano, em intercâmbio com a natureza, realizada pela atividade docente, em parte, é capturada pelo capital. O constante incremento da inovação tecnológica, a produtividade expressa em mais-produto, mediante a relação de trabalho desenvolvida na docência no campo das ciências agrárias, revela-se como condição geral do processo de produção capitalista. A ciência aplicada às tecnologias na agricultura, engendrada pelo trabalho docente, potencializa a produtividade do trabalho, em relação ao valor das mercadorias. 
Pode-se afirmar que o aperfeiçoamento e o incremento de meios de produção voltados, de modo particular, para o melhoramento e para o aumento da produtividade da agricultura, seja por meio da tecnologia de alimentos, seja pela mecanização agrícola, como objeto do trabalho docente, correspondem ao aumento das forças produtivas pelo trabalho intelectual.

Isto é, há trabalho qualificado cuja aplicação tecnológica constitui uma destreza especializada do trabalhador que, consequentemente, amplia a produtividade do trabalho. A inovação científica reduz a unidade de tempo de trabalho necessário, em função da implementação contínua da maquinaria. Isso intensifica a extração de tempo de trabalho, ou seja, isso significa extração de trabalho excedente, portanto, de mais-valia (valor excedente).

Nesse sentido, a força de trabalho do trabalhador docente tem a sua natureza alterada, modificada a partir da ampliação das forças produtivas, pois o valor que incorpora à mercadoria é qualitativamente maior que o valor no qual se baseia a sua força de trabalho que, por sua vez, define a sua remuneração.

\section{O caráter produtivo da atividade docente.}

Afirma Marx, em O Capital:

Os métodos rotineiros e irracionais da agricultura são substituídos pela aplicação consciente, tecnológica, da ciência. O modo de produção capitalista completa a ruptura dos laços primitivos que, no começo, uniam a agricultura e a manufatura. Mas, ao mesmo tempo, cria as condições materiais para uma síntese nova, superior, para a união da agricultura e da indústria, na base das estruturas que desenvolveram em mútua oposição (MARX, 2013, p. 570).

A síntese que fazemos da atividade intelectual no modo de produção capitalista moderno pode ser um exemplo do que Marx expressava quanto à produção capitalista levar, por um lado, ao aumento da força produtiva, como na indústria, e, por outro, ao progresso da agricultura moderna - assim como as fontes originais de toda riqueza, a terra e o trabalhador estariam aprisionados ao domínio do capital. 
A revolução realizada pela indústria moderna na agricultura é, na atualidade, algo sobre a qual não era possível Marx escrever com precisão, mas é incrível verificar em seus textos que o modo de produzir a partir da aplicação consciente da tecnologia e da ciência modifica as relações sociais dos agentes de produção.

Retomando a um exemplo citado anteriormente, em relação ao trabalho docente ligado ao aperfeiçoamento da ferramenta Agricultura de Precisão, podese compreender que tal atividade é um exemplo das mais complexas consequências do desenvolvimento da indústria de máquinas agrícolas, de técnicas de agricultura que buscavam e que buscam lidar com "variabilidade espacial de características do solo" (MOLIN; AMARAL; COLAÇO, 2015).

Trata-se de uma busca de modo contínuo por criar novas técnicas ou meios de trabalho, bem como aperfeiçoar as técnicas de mapeamento da produtividade das lavouras de grãos e de aplicações de georreferenciamento na agricultura.

As primeiras atividades de utilização e de implementação da Agricultura de Precisão começaram a ser difundidas pelas universidades: Escola Superior de Agricultura "Luiz de Queiroz" da Universidade de São Paulo (Esalq/USP), Universidade Federal de Santa Maria (UFSM) e a Universidade Federal de Viçosa (UFV). Hoje, no Brasil, a Agricultura de Precisão está em implementação e aperfeiçoamento, outras instituições passaram a trabalhar com essa nova perspectiva inovadora, inclusive os Institutos Federais de Educação, Ciência e Tecnologia.

Esse desenvolvimento tecnológico quanto aos sistemas de produção agrícola substitui os sistemas de produção anteriores, considerados uniformes, cujas técnicas de manejo não consideravam a grande variabilidade da produção e da qualidade hoje detectada; isso requereu uma nova formação da mão de obra e novas experimentações.

A Agricultura de Precisão é uma prática de agricultura em implementação, tendo como base um sistema de gerenciamento de informações de variabilidade do solo e do clima alinhado com processos de plantação e de colheita, a cada momento, essa técnica cresce em potencial, a partir da introdução de métodos e 
de avanços tecnológicos, por meio da utilização e da criação de novas e aperfeiçoadas formas de operacionalização da produtividade da agricultura, tais como a inclusão do Sistema de Posicionamento Global (GPS) e as tecnologias de sensoriamentos remotos, ambos aplicados à agricultura.

Esse valor produzido pela capacidade do trabalho intelectual contribui diretamente para a elevação do montante total dos lucros do capital. As técnicas e as ferramentas produzidas pelo trabalho intelectual aparecem na sociedade como meios e condições do processo de trabalho que, sob o domínio do capital, constitui valores.

Ou seja, a inovação tecnológica, produto do trabalho, toma forma dominada pelas leis do mercado capitalista, que são utilizadas para a maximização do lucro e para o aumento da expropriação do trabalho alheio. $O$ produto da atividade docente aparece como um valor de uso útil às determinações formais do processo de produção, com vista à valorização do capital.

\section{Considerações finais}

O trabalho docente em análise aparece como elemento presente no desenvolvimento das forças produtivas sociais e constitui fator subjetivo de transformações no processo de valorização do capital. O que nos permite apreender que a sua essência, assim como demonstrado, configura novas formas de organização da produção material e social.

O trabalho docente, em determinadas circunstâncias, no processo social de produção, além de reproduzir valor, cria novos valores. Podemos afirmar que o trabalho docente, em relação à produção de inovação tecnológica, por exemplo, engendra 0 desenvolvimento das forças produtivas, especialmente na acumulação da massa material e na incrementação e no aperfeiçoamento da maquinaria.

Percebemos que o caráter técnico-científico da atividade docente altera a forma de se produzir mercadorias e, consequentemente, amplia as possibilidades 
de apropriação de mais-valia, transformando os processos de trabalho, reduzindo em larga medida a intervenção humana no processo de produção social.

O resultado do trabalho docente, tanto no campo da agricultura quanto na agroindústria, de modo particular, tem contribuído para a ampliação da produção agrícola, a partir da aplicação da ciência e da tecnologia. $O$ que, consequentemente, tem ampliado a velocidade da produção nesse setor, reduzindo os custos da fase produtiva. A invenção contínua, efetivada pelo trabalho docente, para além do papel de educar para o trabalho qualificado (conservação e reprodução da classe trabalhadora), propicia em larga escala o aumento da produtividade social do trabalho.

Em síntese, as invenções tecnológicas produzidas e em aperfeiçoamento, aplicadas no processo de produção, têm acelerado a produção crescente de alimentos e o incremento de matéria-prima para a indústria, além de terem ampliado os ramos das pesquisas de aplicação tecnológica na agricultura. Assim, toda essa produção, de modo geral, é convertida em instrumentos de apropriação de mais-valia.

Esses produtos do trabalho docente são convertidos em meios de acumulação do capital, ou seja, sob o domínio dos capitalistas, tais produtos são convertidos em mercadorias, o que pressupõe a sua reconversão em capital. Nesse sentido, a atividade intelectual é produtiva para o capitalista e para o Estado (MARX, 2013), pois se constitui em meio de produção da riqueza privada.

O trabalho docente na área da agricultura, nos exemplos apresentados, tem mostrado dimensões que possibilitam $o$ incremento expressivo $e$ potencialmente produtivo do ponto de vista social, o que expressa um caráter vantajoso para a reprodução ampliada do capital.

Os trabalhos intelectuais nesse setor têm engendrado novas formas de produzir, criando novas variedades de extração de mais-trabalho, por exemplo: o milho híbrido, o milho $B t$, novas e aprimoradas formas de reprodução de animais, o plantio e a colheita mecanizada, etc; ou seja, aos velhos meios de trabalhos têm sido incorporadas novas funções, a partir da aplicação da ciência.

O incremento crescente da produção de valor de uso pelo trabalho intelectual possibilita o aumento da produtividade do trabalho, a produção dos 
trabalhos que mostramos acima aparece como contradição da capacidade de produzir: por um lado, é a capacidade social de produzir valor de uso para suprir uma necessidade humana; por outro, é expressão da capacidade de produzir valor, esforço de trabalho usurpado pela necessidade de ampliar em proporção superior a forma de reprodução de capital.

A aplicação da tecnologia transforma a natureza em objeto útil à produção, ou seja, o dispêndio da força de trabalho intelectual é fonte para produzir riqueza em sua forma determinada.

A atividade intelectual do professor, para além da transferência de saberes e habilidades, torna-se um componente da produção material. Nesse sentido, concordamos com Cotrim (s/d, p. 4), quando afirma: "[...] o trabalho intelectual não somente é compatível com a produção em forma capitalista, como é posto como força produtiva central pelo próprio capital".

Em relação ao trabalho docente em análise, enfatiza-se a contribuição do esforço intelectual para a construção de possibilidades concretas da transformação social, que se encontram na objetivação do trabalho, em última análise, o trabalho docente aparece consubstanciado à produção e à transferência de valor, o que faz, em determinadas circunstâncias, gerar maisvalia, esse caráter da atividade não só é compatível com a produção na forma capitalista, mas também demonstra potencialmente a possibilidade de existência do sujeito revolucionário diante da dinâmica atual do capital, o que, para nós, constitui a grande questão.

\section{Referências}

CARCANHOLO, Reinaldo A. Capitalismo contemporâneo e trabalho produtivo. Revista de Economia, v. 34, n. especial, 2008.

COTRIM, Vera Aguiar. Trabalho produtivo intelectual e desenvolvimento capitalista em Marx: uma apresentação do problema. Disponível em: $<\mathrm{ttp}: / /$ www.herramienta.com.ar/coloquios-y-seminarios/>. Acesso em: 15 jun. 2017.

FELLOWS, P.J. Tecnologia do processamento de alimentos: princípios e prática. 2. ed. Porto Alegre: Artmed, 2006. 
LONDRES, Flavia. Transgênicos no Brasil: as verdadeiras consequências. Disponível em: <http://www.unicamp.br/fea/ortega/agenda21/candeia.htm>. Acesso em: 23 mai. 2017.

MARX, Karl. Contribuição à crítica da economia política. 2. ed. São Paulo: Expressão Popular, 2008. . Manuscritos econômico-filosóficos. São Paulo: Boitempo, 2010. . O capital: capítulo VI inédito. 2. ed. São Paulo: Centauros, 2004. . O capital: crítica da economia política. Livro I, Vol. I. 31. ed. Rio de Janeiro: Civilização Brasileira, 2013.

Janeiro: Civilização Brasileira, 2014. O capital: crítica da economia política. Livro I, Vol. II. 28. ed. Rio de - Teorias da mais-valia: história crítica do pensamento econômico. Livro I. Rio de Janeiro: Civilização Brasileira, 1987.

MESZÁROS, István. A teoria da alienação em Marx. São Paulo: Boitempo, 2006. MOLIN, José Paulo; AMARAL, Lucas Rios; COLAÇO, André Freitas. Agricultura de precisão. São Paulo: Oficina de Textos, 2015.

NETTO, José Paulo; BRAZ, Marcelo. Economia política: uma introdução crítica. 8. ed. São Paulo: Cortez, 2012.

ROSDOLSKY, Roman. Gênese e estrutura de O capital de Karl Marx. Rio de Janeiro: EDUERJ; Contraponto, 2001.

RUBIN, Isaak Illich. A teoria marxista do valor. São Paulo: Editora Polis, 1987.

TEIXEIRA, Francisco José Soares. Pensando com Marx: uma leitura críticocomentada de O capital. São Paulo: Ensaio, 1995.

Recebido em: 28 de dezembro de 2018. Aprovado em: 21 de março de 2018. Publicado em: 13 de junho de 2018. 